\title{
FEMINISME DALAM POLITIK PADA CERPEN WAKYAT KARYA PUTU WIJAYA
}

Feminism in Politics in the Short Story Entitled Wakyat Written by Putu Wijaya

\section{SUHAILAH NAILI SALSABILA}

\author{
Program Studi Magister Kajian Sastra dan Budaya \\ Fakultas Ilmu Budaya Universitas Airlangga \\ Jl. Dharmawangsa Dalam Selatan, Surabaya 60286 \\ E-mail: salsabila0895@gmail.com
}

\begin{abstract}
Abstrak: Penelitian ini menggunakan teori kritik sastra feminis untuk melihat adanya sikap feminis yang dapat mempengaruhi pemikiran tokoh-tokoh dalam cerpen Wakyat karya Putu Wijaya. Selain itu, untuk menjelaskan adanya peran feminis dalam politik mampukah membawa dampak yang lebih baik dalam dunia perpolitikan. Jadi, harapan peneliti mengenai penelitian melalui cerpen Wakyat karya Putu Wijaya menggunakan feminis dengan pendekatan semiotik dapat memberi warna baru dalam memandang karya Putu Wijaya, sehingga dapat menghasilkan penelitian yang baru melalui karya Putu Wijaya dengan analisis yang berbeda dan baru. Metode yang digunakan dalam penelitian ini adalah kajian dokumen (library research). Pendekatan penelitian ini menggunakan pedekatan ekspresif. Hasil yang ditemukan dari penelitian ini yaitu pergerakan feminis yang berupa emansipasi wanita tidak hanya berupa tindakan tapi juga perkataan, petanyaan, pernyataan yang dapat mengubah pemikiran orang lain untuk bergerak maju menunjukkan kebenaran dan kesetaraan.
\end{abstract}

Kata Kunci: Feminisme, Politik, Wakyat

\begin{abstract}
This study uses feminism to see the existence of feminist attitudes in Mrs. Amat that can influence Mr. Amat's thoughts when recalling the events of fraud by the People's Deputy in his environment. In addition, this study aims to explain the role of feminists in politics can be a better impact in the sense of politics. Using feminism and a semiotic approach, I hope this study can give a new insight in looking at Putu Wijaya's work. The method used in this research is document research (library research). The results found in this study are feminist movements in the form of emancipation of women not only in the form of actions but also words, questions, statements that can change the thinking of others to move forward to show truth and equality.
\end{abstract}

Key Words: Feminism, Politics, Wakyat 


\section{PENDAHULUAN}

Dalam dunia politik atau hukum saat ini sudah tidak seperti zaman dahulu, di mana dahulu yang mengetahui dan mempelajari kedua hal tersebut kebanyakan adalah lakilaki. Sekarang, perempuan pun sudah banyak yang tahu dan mengerti serta mempelajari kedua hal tersebut. Tidak sedikit perempuan di masa sekarang yang juga ikut terjun langsung di dunia politik maupun hukum. Meskipun mereka juga ada yang tidak berkecimpung langsung di dunia politik maupun hukum, para perempuan masa kini menggunakan pengetahuannya tentang kedua hal tersebut untuk mengamati perkembangan politik dan hukum yang sedang berkembang dan terjadi di sekitar mereka, khususnya di Indonesia.

Komisioner Komnas Perempuan Masruchah melalui (news.okezone.com), berpendapat mengenai penguatan peran dan kapasitas perempuan baik di parlemen maupun di pemerintah harus didasarkan pada suatu sistem, bukan didasarkan pada pribadi atau perorangan. Idealnya, seorang politikus perempuan juga bisa independen, dan bahkan bicara atas nama partai.

Sementara itu, aktivis perempuan dan anak, Erlinda melalui (news.okezone.com) juga berharap perempuan dapat memberikan kontribusi nyata berupa solusi dalam bentuk program dan kebijakan. Ia menekankan pada seluruh pihak di legislatif dan eksekutif mempunyai kompetensi, dedikasi, komitmen dan memperjuangkan kepentingan kaum perempuan. Menurut Erlina, "Perempuan akan menguatkan negara dan bangsa apabila ada keseimbangan dalam kedudukan dan kesetaraan."
Media sosial yang masih menjadi peran utama dan penting di dunia yang semakin canggih ini, merupakan alat yang paling cepat dan dekat untuk menyebarkan berita ataupun mencari berita terkini. Hal ini lah yang menjadikan semua orang zaman sekarang tidak gagap teknologi akan berita atau peristiwa terbaru yang terjadi di sekitar. Tidak pandang Laki-laki atau Perempuan , jika mereka menguasai pengetahuan dalam dunia canggih saat ini mereka akan mudah mengikuti zaman dan membuka wawasan.

Melalui pernyataan Bung Karno dalam (m.kumparan.com) "Perempuan Indonesia, kewajibanmu telah terang, sekarang ikutlah serta ikutlah dalam usaha menyelamatkan Republik, dan jika Republik telah selamat, ikutlah serta mutlak dalam usaha menyusun Negara Nasional. Janganlah tertinggal dalam Revolusi Negara dari awal hingga akhir, dan jangan tertinggal pula di dalam usaha menyusun masyarakat berkeadilan sosial dan kesejahteraan sosial. Di dalam masyarakat berkeadilan sosial dan kesejahteraan sosial itulah engkau akan menjadi wanita bahagia, wanita merdeka".

Putu Wijaya selain berteater atau drama juga menulis cerita pendek. Sejumlah cerita pendeknya muncul, baik yang berupa buku maupun yang terbit di berbagai majalah dan surat kabar. Sama seperti drama dan novelnya, cerita pendek Putu Wijaya juga bercorak baru, beraliran kesadaran baru, dan mengungkapkan banyak arus kesadaran (stream of consciousness). Banyak kritikus dan pengamat sastra yang memberikan kritik dan komentar terhadap Putu Wijaya. A. Teeuw menyatakan bahwa Putu Wijaya adalah orang yang sangat energetik dan serbabisa. Dia 
bukan hanya wartawan dan anggota tetap staf redaksi majalah Tempo, melainkan juga sutradara dan penulis drama. Unsur keterasingan (sebagai ciri khas manusia modern) makin jelas dalam novel-novelnya. Di sinilah ia menunjukkan bakatnya sebagai novelis sepenuh-penuhnya.

Sosok "Pak Amat" dalam cerpen Wakyat karya Putu Wijaya yang dimuat harian Kompas tanggal 28 April 2019, merupakan orang yang lupa dan tidak sadar akan peristiwa yang pernah menimpa lingkungannya. Setelah pertanyaan dari istrinya $\mathrm{Bu}$ Amat, ia mulai mengingat dan berpikir terjadinya peristiwa tersebut bisa terjadi di lingkungannya. Setelah mengingat terjadinya semua peristiwa tersebut Pak Amat dapat menyimpulkan melalui hal yang diungkit kembali oleh $\mathrm{Bu}$ Amat dapat menjelaskan bahwa rasa malu warga yang ada dilingkungannya atau dirinya sendiri pun sudah mulai hilang akibat terkena tipu oleh Wakil Rakyat, malu tersebut hanya akan membuat konyol karena takut akan bertindak. Kemudian juga mengatakan bahwa "kaum perempuan selalu jadi pelopor kebangkitan!"

Melalui fenomena tersebut, yang digambarkan melalui pemikiran Pak Amat. Terdapat beberapa rumusan masalah mengenai hal tersebut: (1) bagaimana feminisme dalam politik pada cerpen Wakyat karya Putu Wijaya? (2) apakah peran feminis dalam politik dapat menjadikan dunia pemerintahan menjadi lebih baik pada cerpen Wakyat karya Putu Wijaya?

Untuk dapat menjawab dan menjelaskan rumusan masalah tersebut. penelitian ini akan menggunakan teori feminis. Untuk melihat adanya sikap feminis dalam diri $\mathrm{Bu}$ Amat yang dapat mempengaruhi pemikiran Pak Amat saat mengingat kembali peristiwa penipuan oleh Wakil Rakyat dalam lingkungannya. Selain itu, untuk menjelaskan adanya peran feminis dalam politik mampukah membawa dampak yang lebih baik dalam dunia perpolitikan.

\section{Feminisme}

Feminisme lahir awal abad ke 20, yang dipelopori oleh Virginia Woolf melalui bukunya yang berjudul A Room of One's Own (1929). Feminis berasal dari kata femme (woman) yang artinya perempuan dan bertujuan untuk memperjuangkan hak-hak kaum perempuan, sebagai kelas sosial. Jadi, feminisme adalah gerakan kaum wanita untuk menolak segala sesuatu yang dimarginalisasikan, disubordinasikan, dan direndahkan oleh kebudayaan dominan, baik dalam bidang politik dan ekonomi maupun kehidupan sosial pada umumnya.

Dalam teori sastra kontemporer, feminis merupakan gerakan perempuan yang terjadi hampir di seluruh dunia. Gerakan ini dilatarbelakangi oleh kesadaran bahwa hakhak kaum perempuan sama dengan kaum laki-laki. Dalam kaitannya dengan sastra, bidang studi yang relevan diantaranya mengenai: tradisi literer perempuan, pengarang perempuan, pembaca perempuan, ciri-ciri khas bahasa perempuan, tokoh-tokoh perempuan, dan sebagainya.

Julia Kristeva, memunculkan feminisme melalui tampilan teks sebagai material produksi yang merupakan dekonstruksi hegemoni budaya barat. Konsepnya yang paling terkenal adalah semanalysis, metode yang memusatkan 
perhatian bukan semata-mata pada fungsi bahasa sebagai sarana komunikasi, melainkan melalui material bahasa, seperti: suara, irama, dan ciri grafis. Kristeva juga seorang kritik feminis. Ketertarikannya pada feminis berangkat dari teori Freud dan Lacan yang menganggap perempuan sebagai makhluk lemah.

Kristeva memberikan perhatian subjektivitas dan aspek sosial historis dunia penandaan (semiotika). Semiotik tersebut sebagai feminis. Menurut pendapatnya, bahasa bukan sistem yang monolitik, melainkan proses penandaan yang kompleks, heterogen yang ada di dalam dan di antara subjek, dari struktur homogeny ke arah bahasa sebagai proses heterogen.

Dalam Women Time's mengatakan bahwa feminis bergerak dalam gelombang. Subjektivitas perempuan berhubungan dengan waktu yang berulang (cyclicalrepetition) dan waktu monumental (keabadian). Keduanya merupakan cara untuk mengonseptualisasi waktu berdasarkan perspektif motherhood dan reproduksi. Waktu dalam sejarah, di lain pihak, adalah waktu yang linear: Waktu sebagai proyek, kemajuan, kedatangan dan sebagainya. Tiga gelombang feminis menurut Kristeva, sebagai berikut: (1) Feminis Egalitarian, yaitu menuntut hak sejajar dengan laki-laki, dengan perkataan lain, hak-haknya untuk memperoleh tempat dalam waktu yang linear. (2) Generasi Kedua, muncul setelah tahun 1968. Menekankan perbedaan radikal perempuan dari laki-laki dan menuntut hak perempuan untuk tetap berada di luar waktu linear, sejarah dan politik. (3) Feminisme Generasi Ketiga, mendorong eksistensi yang pararel dengan menggabungkan ketiga pendekatan feminis yang memungkinkan perbedaan individu untuk tetap ada tanpa menjadi kehilangan feminitasnya.

Teori feminisme telah memberikan kontribusi kunci atas diskursus modernitas dengan kritik atas dimensi gender biner dan bagaimana pola kekuasaan dibangun di antara keduanya. Analisis gender menarasikan bagaimana dinamika kekuasaan terlampirkan dalam diferensiasi ruang privat dan publik. Divisi-divisi ini kemudian mereproduksi ketaksetaraan, ketakadilan, kejanggalan yang kemudian melakukan devaluasi dan penolakan renumerasi atas kerja-kerja perempuan di rumah, yang juga tereplika ketika perempuan bekerja di rumah perempuan lain (Fraser, 1987; Pateman, 1989; hooks, 1990).

Fokus kajian feminis dalam sastra berhubungan dengan konsep kritik sastra feminis. Sastra yang mengarahkan fokus analisis terhadap wanita. Kritik sastra feminis bukan dimaksud sebagai pengeritik wanita, atau kritik tentang wanita, atau kritik tentang pengarang wanita. Pengeritik yang dinmaksud di sini adalah memandang sastra dengan kesadaran khusus; kesadaran bahwa ada jenis kelamin yang banyak berhubungan dengan budaya, sastra, dan kehidupan. Membaca sebagai wanita maksudnya membaca dengan kesadaran membongkar praduga dan ideologi kekuasaan laki-laki yang androsentris atau patrialkal, yang sampai detik ini masih menguasai penulisan dan pembacaan sastra. Perbedaan jenis kelamin pada diri penyair, pembaca, unsur karya dan faktor luar yang menjadi pengaruh situasi sisitem komunikasi sastra. 
Endraswara (2013) mengungkapkan bahwa dalam menganalisis karya sastra menggunakan kajian feminisme yang difokuskan adalah (a) kedudukan dan peran tokoh perempuan dalam sastra, (b) ketertinggalan kaum perempuan dalam segala aspek kehidupan, termasuk pendidikan dan aktivitas kemasyarakatan, (c) memperhatikan faktor pembaca sastra, bagaimana tanggapan pembaca terhadap emansipasi wanita dalam sastra.

Menurut Salden (1986: 130-131), ada lima masalah yang biasa muncul dalam kaitannya dengan teori feminis, yaitu (a) masalah biologis, (b) pengalaman, (c) wacana, (d) ketaksadaran, dan (e) masalah sosioekonomi. Penyebab utama dalam teori feminis adalah sebagai akibat masalah wacana sebab perempuan sesungguhnya termarginalisasikan melalui wacana yang dikuasai oleh laki-laki. Pada dasarnya teori feminis di bawa ke Indonesia oleh A. Teeuw. Fakta ini yang membuktikan bahwa teori Barat dapat dimanfaatkan untuk menganalisis Sastra Indonesia, dengan catatan bahwa teori adalah alat, bukan tujuan.

Feminisme sebagai gerakan kaum perempuan untuk memperoleh otonomi atau kebebasan menentukan dirinya sendiri. Feminisme memperjuangkan dua hal yang selama ini tidak dimiliki kaum perempuan pada umumnya, yaitu persamaan derajat mereka dengan laki-laki dan umumnya, yaitu persamaan derajat mereka dengan laki-laki dan otonomi untuk menentukan ap yang baik bagi dirinya (Yasa, 2012: 37)

Dari teori feminis yang sudah dijelaskan di atas dan fokus kajiannya, penelitian ini mencoba berfokus pada kedudukan dan peran tokoh perempuan dalam sastra dan melihat faktor pembaca sastra mengenai emansipasi wanita dalam sastra. Hal ini dapat digunakan untuk menelusuri feminisme dalam politik pada cerpen Wakyat karya Putu Wijaya. Sedangkan unsur semiotik yang ada dalam feminis untuk menelusuri dan menunjukkan peran feminis dalam politik yang dapat membawa dampak dalam dunia pemerintahan pada cerpen Wakyat karya Putu Wijaya.

Mengenai penganalisisan cerpen karya Putu Wijaya, pada penelitian yang telah dilakukan oleh Nuraeni (2017) dalam cerpen 2011 karya Putu Wijaya, ia menggunakan struktural dan semiotik. Struktur digunakan untuk melihat struktur cerpen tersebut secara utuh dan semiotik untuk melihat adanya tanda yang juga menjadi keunikan dalam cerpen tersebut. Melalui struktur tersebut dapat melihat dan menemukan adanya tokoh yang miliki jiwa Nasionalisme yang tinggi, sedangkan semiotik dapat melihat dan menemukan adanya tanda salah satunya dari judul cerpen itu sendiri yaitu 2011 yang dimaksudkan dalam cerpen ini bahwa setiap akhir tahun dan menyambut awal tahun setiap orang mempunyai harapan untuk bisa lebih baik lagi dari kemarin, namun nyatanya saat sudah menikmati tahun baru terasa sama saja dengan tahun kemarin, seperti tidak apa kemajuan atau perubahan.

Dalam banyak penelitian yang membahas perempuan dalam relasinya dengan agama dan politik, amat jarang meletakkan perempuan sebagai agen aktif dalam perjuangannya. Hasil penelitian sebuah disertasi, naskah tersebut mencontohkan bagaimana perempuan bergerak melawan 
dan bersuara untuk dirinya menuju sumbersumber kekuasaan, atas tafsir, atas politik kenegaraan. Buku-buku sebelumnya yang banyak membahas perempuan sebagai agen politik dalam gerakan religius juga telah ada dalam lokus yang berbeda dari Indonesia, yaitu di Timur Tengah (Epstein 1981; Mahmood 2005; Deeb 2006). gender, agama dan politik bukanlah entitas-habis (esensialis), tetapi sebagai sebuah dimensi yang dapat berubah sesuai dengan pelekatan waktu, tempat dan lokasi kesejarahannya.

Jadi, harapan peneliti mengenai penelitian melalui cerpen Wakyat karya Putu Wijaya menggunakan feminis dengan pendekatan semiotik dapat memberi warna baru dalam memandang karya Putu Wijaya, sehingga dapat menghasilkan penelitian yang baru melalui karya Putu Wijaya dengan analisis yang berbeda dan baru.

\section{METODE}

Metode merupakan cara-cara, strategi untuk memahami realitas, langkah-langkah sistematis untuk memecahkan rangkaian sebab akibat berikutnya (Nyoman, 2004: 34) Sumber data yang digunakan berupa cerpen Wakyat karya Putu Wijaya yang dimuat oleh harian Kompas pada tanggal 28 April 2019. Novel ini mengangkat feminisme dari tokoh Pak Amat dan istrinya.

Analisis dilakukan terhadap kutipan kata, kalimat atau paragraf dari cerpen Wakyat karya Putu Wijaya, dengan syarat data harus memuat feminisme dalam politik pada cerpen Wakyat karya Putu Wijaya dan peran feminis dalam politik yang dapat menjadikan dunia pemerintahan menjadi lebih baik atau tidak pada cerpen Wakyat karya Putu Wijaya.

Endraswara (2013) menjelaskan bahwa metode penelitian dalam sastra merupakan cara peneliti untuk mempertimbangkan bentuk, isi, dan sifat sastra yang mejadi subjek kajian. Tapi, sering kali dalam penelitian sastra terdapat kerancuan mengenai istilah metode yang berakibat adanya tumpang tindih pada wilayah penelitian sastra. Yang benar, yaitu menjelaskan cara yang operasional dalam penelitian seperti menunjukkan langkahlangkah penelitian yang dapat diikuti.

Metode yang digunakan dalam penelitian ini adalah kajian dokumen (library research). Penelitian ini akan menggunakan teks dalam cerpen Wakyat karya Putu Wijaya sebagai data atau mencari informasi mengenai feminis dalam politik dan peran feminis yang mampu mengubah dunia Pemerintahan. Setelah mengumpulkan data dengan cara membaca dan mendalaminya, data tersebut dicatat dari yang berupa kata, kalimat, dan paragraf yang berangkutan dengan rumusan masalah penelitian yang akan dibahas.

Menurut pendapat Abrams (1976) pendekatan dalam karya sastra ada empat yaitu pendekatan mimetik, ekspresif, pragmatik dan objektif. Penelitian ini akan berfokus menggunakan pendekatan ekspresif. Pendekatan ekspresif tidak semata-mata memberikan perhatian terhadap bagaimana karya itu diciptakan terhadap bentuk-bentuk apa yang terjadi dalam karya sastra yang dihasilkan. Wilayah studi pendekatan ini adalah diri pengarang, pikiran dan perasaan dan hasil-hasil karyanya. Pendekatan ini dapat dimanfaatkan untuk menggali ciri-ciri individualisme, feminisme, dan sebagainya dalam karya baik karya sastra individual maupun karya sastra dalam kerangka periodisasi.

Pendekatan ekspresif menempatkan karya sastra sebagai curahan, ucapan, dan proyeksi pikiran dan perasaan pengarang. Pengarang sendiri menjadi pokok yang melahirkan produksi persepsi-persepsi, pikiran-pikiran, dan perasaan-perasaan yang dikombinasikan. Jadi, secara metodis, langkah kerja yang dapat dilakukan melalui 
pendekatan ini adalah (1) memberikan sejumlah pikiran, persepsi, dan perasaan pengarang yang hadir secara langsung atau tidak di dalam karyanya. (2) memetakan sejumlah pikiran, persepsi, dan perasaan pengarang yang ditemukan dalam karyanya ke beberapa kategori faktual teks berupa watak, pengalaman, dan ideologi pengarang. (3) merujukkan data yang diperoleh pada tahap (1) dan (2) ke dalam fakta-fakta khusus menyangkut watak, pengalaman hidup, dan ideologi pengarang secara secara faktual luar teks (data sekunder berupa data biografis), dan (4) membicarakan secara menyeluruh, sesuai tujuan, pandangan dunia pengarang dalam konteks individual maupun sesuai dengan mempertimbangkan hubunganhubungan teks karya sastra hasil ciptaannya dengan data biografinya.

Teknik analisis sebagai sarana untuk memecahkan atau menganalisis masalahmasalah yang diperoleh dari sejumlah data yang sudah dikumpulkan. Validitas sebagai ukuran keabsahan data sebagai objek penelitian yang dapat dijelaskan oleh peneliti. Jadi, validitas data merupakan persamaan data "yang tidak berbeda" dari data lapangan atau yang ditemukan dengan data yang dilaporkan oleh peneliti.

Adapun teknis analisis berhubungan dengan proses pengumpulan data dan analisis penelitian sebagai berikut. Pertama, melakukan kajian dokumentasi yaitu membaca secara mendalam atau berulang cerpen Wakyat karya Putu Wijaya hingga selesai. Kedua, mengumpulkan atau menandai data berupa kata, kalimat, dan paragraf yang mengandung feminisme dalam politik pada cerpen Wakyat karya Putu Wijaya dan peran feminis dalam politik yang dapat menjadikan dunia pemerintahan menjadi lebih baik atau tidak pada cerpen Wakyat karya Putu Wijaya. Ketiga, menyusun data yang berupa kata, kalimat, dan paragraf yang mengandung feminisme dalam politik pada cerpen Wakyat karya Putu Wijaya dan peran feminis dalam politik yang dapat menjadikan dunia pemerintahan menjadi lebih baik atau tidak pada cerpen Wakyat karya Putu Wijaya untuk diidentifikasi dan dianalisis menggunakan feminisme Julia Kristeva yang melihat unsur feminisme dari teks yang juga bisa sebagai semiotik. Setelah itu, agar tidak berhenti dalam interpretasi saja akan dilanjutkan lebih mendalam dengan memberi kritik, pendapat atau alasan atas pengaplikasian teori feminisme Kristeva dalam kata, kalimat, dan paragraf tersebut sehingga mendapat jalan keluar untuk masalah tersebut. Keempat, setelah bagian feminisme dalam politik pada cerpen Wakyat karya Putu Wijaya dan peran feminis dalam politik yang dapat menjadikan dunia pemerintahan menjadi lebih baik atau tidak pada cerpen Wakyat karya Putu Wijaya terjelaskan dengan benar dan jelas maka dapat mengetahui tujuan dan pesan cerpen Wakyat karya Putu Wijaya melalui permasalahan yang telah dihadirkan.

\section{HASIL DAN PEMBAHASAN \\ Feminisme Dalam Politik Pada Cerpen Wakyat Karya Putu Wijaya}

$\mathrm{Bu}$ Amat merupakan wanita yang memiliki keingintahuan sangat tinggi. Ia tidak seperti wanita pada umunya yang tidak peduli mengenai pemerinah atau masalah politik yang ada disekitarnya, sehingga ia bertanya kepada suaminya. Namun malah suaminya kurang mengikuti perkembangan berita politik yang ditanyakan bu Amat. Keingintahuan yang tinggi dalam diri Bu Amat juga memiliki sebab, ternyata Bu Amat adalah seorang Guru sehingga tidak diragukan lagi bahwa ia memiliki banyak pengetahuan dan memiliki pemikiran yang luas apa yang ia ketahui dalam lingkungannya.

Pemikiran Pak Amat yang ingin mengubah rasa malu yang membuat konyol orang-orang karena terkena penipuan untuk berubah menegakkan hukun dengan benar, 
hal tersebut karena pertanyaan istrinya $\mathrm{Bu}$ Amat mengenai Pak Amat. Jadi Pak Amat mengatakan bahwa "kebangkitan memang bisa dimulai dari kaum perempuan".

Mengenai hasil temuan yang sudah dijelaskan di atas, maka lebih rinci lagi akan diberi kutipan dan pembahasan sebagai berikut:

$\mathrm{Bu}$ Amat tiba-tiba menodong suaminya. "Sejatinya Wakyat itu siapa, Pak?" (Wijaya, 2019)

Dalam kutipan di atas "menodong" dapat diartikan sebagai mendesak suaminya, Pak Amat diminta segera menjawab pertanyaan $\mathrm{Bu}$ Amat mengenai Wakyat. Hal tersebut merupakan pertanyaan untuk meastikan bahwa suaminya tersebut tahu atau tidak pula akan sosok Wakyat yang telah menorehkan kesan yang tidak baik bagi mereka ataupun orang-orang di sekitar Pak Amat dan $\mathrm{Bu}$ Amat.

Selain itu feminis yang terliat dari kutipan tersebut dengan menodong yang tidak biasanya dilakukan oleh perempuan kepada laki-laki, telah dilakukan oleh Bu Amat kepad Pak Amat. Sehingga hal tersebut menampakkan bahwa Bu Amat tidak menjadi istri yang bisa mengiyakan perkataan suami, $\mathrm{Bu}$ Amat juga mempunyai pemikiran danpernyataan sendiri mengenai Wakyat atau wakil rakyat yang tidak becus mengurus rakyat.

Kutipan berikutnya:

Ibu ini dulu kan guru bahasa Indonesia, sekarang kok bahasanya mundur sekali! Ngomongnya yang bener dong! Jangan seperti orang bingung, Ya, ya, ya! Tidak, ya, tidak. Tidak bisa ya dan tidak." (Wijaya, 2019)

Sebagai guru, $\mathrm{Bu}$ Amat tidak akan berbahasa dan berkata secara ambigu tanpa sebab. Berhubung suaminya, Pak Amat belum nyambung dengan pertanyaannya. Maka ia membuat pernyataan yang membuat ia ragu, sehingga Pak Amat kepikiran dan mulai berpikir mengenai pertanyaan $\mathrm{Bu}$ Amat tersebut.

Perempuan yang mempunyai pengetahuan atau ilmu yang luas, pasti memiliki banyak cara untuk mengatasi lawan bicaranya, tidak peduli ia laki-laki terbih lagi suaminya. Bu Amat memancing ingatan Pak Amat yang lupa mengenai Wakyat melalui hal tersebut. karena sebenarnya $\mathrm{Bu}$ Amat menginginkan suaminya juga memikirkan hasil dari pilihan mereka mengenai Wakyat. Orang tersebut seharusnya tidak dilupkan, tapi dipikirkan untuk mengatasi jalan keluar yang disebabkan olehnya sehingga tidak terulang kembali.

\section{Peran Feminis Dalam Politik Yang Dapat Menjadikan Dunia Pemerintahan Menjadi Lebih Baik Pada Cerpen Wakyat Karya Putu Wijaya}

Melaui pertanyaan $\mathrm{Bu}$ Amat kepada Pak Amat, membuat Pak Amat berpikir dan mengubah pandangannya. Mengenai kekonyolan orang-orang saat teringat kasus penipuan yang menimpa mereka mereka tidak harus malu dan membiarkannya. Karena masih ada hukum, dan hukum tersebut harus benar-benar ditegakkan di negara hukum seperti Indonesia.

Setelah bukan laki-laki saja yang mengetahui dan belajar mengenai politik. Perempuan juga dapat mengomentari dan berpendapat mengenai ketidaktepatan pekerjaan seorang wakil rakyat. Sehingga, saat hal tersebut terjadi rakyat tidak bisa dengan mudah dibohongi oleh pemerintah ataupun wakil rakyat untuk tunduk dan mengikuti aturan.

Mengenai hasil temuan yang sudah dijelaskan di atas, maka lebih rinci lagi akan diberi kutipan dan pembahasan sebagai berikut:

Begitu memalukannya lakon penipuan yang canggih, dramatis, 
tertata rapih, lucu dan mengobarkan marah itu, sehingga seluruh warga berusaha melupakannya. Karena setiap teringat, semua orang jadi merasa dirinya begitu konyol.

Jadi kalau $\mathrm{Bu}$ Amat mencoba mengorek lagi, "Berarti malu kita sudah mulai hampir kikis. Sekarang kitaberangsur sembuh dan harus mengusut peristiwa kriminal itu tuntas! Kita harus potong mati. Kalau tidak, percuma kita mengaku negara hukum! Percuma! Kebangkitang memang biasa dimulai dari kaum perempuan," bisik Amat dalam hati. "Malu itu konyol, kita harus bertindak sekarang!" (Wijaya, 2019)

Pada kutipan di atas "konyol" yang dimaksud yaitu kehilangan akal. Siapa saja yang terkena penipuan pasti tidak menyangka akan terjadi hal tersebut. sehingga saat kejadian mereka juga merasa dirinya tidak habis pikir atau kehilangan akal karena tidak berpikir ulang. Sehingga mendatangkan malu atas dirinya juga. Sedangkan "malu yang hampir terkikis" bukan tidak memiliki rasa malu, tapi rasa malu tersebut mulai sirna dalam dirinya mengenai masalah penipuan tersebut sehingga harus bangkit dan melawan untuk perbaikan diri juga pikiran untuk lebih baik. Keberanian harus ditegakkan sehingga siapa pun tidak mudah ditindas ataupun ditipu lagi.

Feminis yang terlihat adanya peran kaum perempuan sebagai kebangkitan. Perempuan yang sebenarnya bertakdir mempunyai rasa peka yang lebih daripada laki-laki, maka mereka dapat dengan mudah merasakan hal-hal yang membuat kehidupan mereka tidak nyaman sebagai perempuan. Kebangkitan, kaum perempuan dari bergantinya zaman mulai menapakkan keberanian dirinya mulai dari menunjukkan dirinya dalam kesetaraan. Jadi, keinginan Pak Amat untuk mengusut perkara penipuan ke ranah hukum lebih lanjut merupakan adanya peran istrinya $\mathrm{Bu}$ Amat yang mengubah pikirannya mengenai Wakyat. Selain itu, adanya peraturan hukum yang diberlakukan di Indonesia sebagai negara hukum membuat Pak Amat ingin menggunakan jalur tersebut sebagai warga yang ingin menuntut kewajibannya sebagai warga yang dirugikan. Kutipan berikutnya:

"Habis. Wakyat itu kan sejatinya wakil rakyat, wakil seluruh rakyat! Tapi kenapa prakteknya hanya wakil partai, wakil kelompok yang kurang peduli nasib rakyat keseluruhannya?!" (Wijaya, 2019)

Kutipan di atas memperlihatkan nada perkataan $\mathrm{Bu}$ Amat sangat kesal, kecewa karena perlakukan Wakyat kurang adil, tidak merata kepada seluruh rakyat yang membutuhkan dirinya. Serta menyayangkan pekerjaannya tidak dapat leluasa karena adanya perintah juga yang mengendalikan diri Wakyat, yaitu dalam partai. Partai dalam kutipan tersebut hanya akan mengurusi program kerja partai yang akan dilaksanakan melalui pemerintahan.

Feminis yang terlihat dari $\mathrm{Bu}$ Amat, ia berani mengutarakan pikirannya mengenai Wakyat yang ia ketahui. Hal ini juga menandai bahwa zaman semakin terbuka dan tidak ada yang memandang atau membatasi antara lakilaki dan perempuan untuk belajar suatu hal di dunia ini. Bu Amat sudah menjadi bukti bahwa perempuan juga bisa mengkritik dunia politik khususnya pemerintahan DPR yang belum maksimal kinerjanya namun malah menorehkan luka kepada rakyat dengan aksi penipuan. Jadi semakin banyak perempuan yang melek dunia politik, semakin banyak orang yang ingin negaranya menjadi lebih baik dan bersih dari tangan kotor oknum- 
oknum yang tidak bertanggung jawab. Serta ingin memperlihatkan negaranya mampu menjadi negara yang lebih jujur dan melayani rakyatnya dengan benar.

\section{SIMPULAN}

Perempuan di zaman sekarang sudah berbeda dengan dengan zaman dahulu, meskipun masih ada penuntutan hak yang sama dengan laki-laki, caranya pun berbeda. Seperti tokoh Bu Amat yang ada dalam cerpen Wakyat karya Putu Wijaya. Feminis yang ditunjukkan oleh $\mathrm{Bu}$ Amat sangatlah halus dan tidak kentara, namun dampaknya akan tersa pada lawan bicaranya yaitu Pak Amat. Pikiran Pak Amat telah dipengaruhi oleh $\mathrm{Bu}$ Amat melalui pendapatnya dan pertanyaannya mengenai Wakyat. Hal tersebut juga didukung oleh tanda-tanda dan nada bicara yang ditunjukkan oleh $\mathrm{Bu}$ Amat dalam cerpen mengenai bahwa dirinya meragukan dan juga kecewa mengenai sosok Wakyat.

Emansipasi, saat ini tidak hanya berupa tindakan tapi juga pernyataan, pendapat yang dimiliki seorang perempuan ataupun laki-laki yang menyangkut kehidupan, hak dan kesetaraan mereka. Adanya kebebasan menyampaikan pendapat bagi siapa saja juga telah menjadi pengaruh mereka untuk saling menunjukkan kesetaraan. Namun, saat hak mereka di rampas ataupun tidak dipenuhi mereka akan lebih suka mengkritik atau menyampaikan langsung melalui tempat pengaduan bagi mereka. Jadi, semakin zaman berubah dan laki-laki atau perempuan samasama saling memiliki pengetahuan yang sama mereka tidak akan membiarkan diri mereka ditindas ataupun dibohongi dengan mudah oleh Pemerintah. Khususnya di bidang politik, mereka sudah tidak menjadi penonton pasif, tapi mereka telah berubah menjadi penonton aktif untuk mengkritisi politik lebih baik lagi.

Melalui pendapat, pernyataan, dan pandangan $\mathrm{Bu}$ Amat femiminisme dalam cerpen Wakyat karya Putu Wijaya dapat terlihat, bahwa perepuan juga bisa dan peduli dalam dunia politik. Pemikirannya telah mengubah pikiran suaminya untuk kembali segera bertindak yang sebelumnya terlambat memantau atau melihat perkembangan Wakyat. Jadi pemikiran dan perkataannya $\mathrm{Bu}$ Amat mampu menggerakkan Suaminya Pak Amat untuk berani maju ke ranah hukum.

Jadi, peran feminis dalam dunia pemerintahan masih berjalan atau masih berproses melalui perempuan-perempuan yang berpikiran lebih terbuka dan maju mulai dari yang langsung terjun dalam politik atau yang hanya sebagai pengamat atau pemantau politik. Namun, tidak menutup kemungkinan bila perempuan pemikirannya semakin menurun mengenai politik maka politik pun dapat tidak berjalan dengan benar, Karena, laki-laki sendiri tidak selalu bisa diandalkan dalam dunia politik, mereka terlalu mengedepankan ambisius mereka tanpa mempedulikan sekitarnya. Mereka hanya dapat melihat permasalahan yang hanya bisa dilihat oleh mata mereka dan tidak bisa melihat permasalahan dari mata hati atau perasaan mereka.

\section{DAFTAR PUSTAKA}

Dorothy W. dkk (1998) Women in Power: Kiprah Wanita Dalam Dunia Politik. Jakarta: Gramedia Pustaka Utama

Endraswara, Swardi (2013) Metode Penelitian Sastra: Epistemologi, Model, Teori, dan Aplikasi. Yogyakarta: CAPS

Fraser, Nancy (1987) What's Critical about Critical Theory? The Case of Habermas and Gender. In Feminism as Critique: Essays on the Politics of Gender in Late-Capitalist Societies, ed. Seyla Benhabib and Drucilla Cornell, pp. 3156. Minnesota: University of Minnesota Press.

Hooks, Bell (1990) Yearning-Race, Gender, and Cultural Politics. Boston: South End

Jurnal Lakon: Kajian Sastra dan Budaya e-ISSN: 2527-4899; p-ISSN 2252-8954 
Jabrohim (2001) Metode Penelitian Sastra. Yogyakarta: PT Putrasetia Widia Pratama

Julia Kristeva, (Toril Moi ed.), (1986) The Kriteva Reader. New York. Columbia University

Kutha Ratna, Nyoman (2004) Teori, Metode, dan Teknik Penelitian Sastra. Denpasar: Pustaka Pelajar

Pateman, Carole (1989) Feminist Critiques of the Public/Private Dichotomy. In The Disorder of Women: Democracy, Feminism and Political Theory, ed. Carole Pateman, pp. 118-40. Cambridge: Polity Press.

Sardjon, Asmowati, dkk (2008) Estetika Sastra, Seni dan Budaya. Fakultas Bahasa \& Seni Universitas Negeri Jakarta

Sariban (2009) Teori dan Penerapan Penelitian Sastra. Surabaya: Lentera Cendikia Surabaya

Sihite, Romany (2007) Perempuan, Kesetaraan, Keadilan. Jakarta: PT. Raja Grafindo Persada

http://ensiklopedia.kemdikbud.go.id/sastra/a rtikel/Putu_Wijaya | Ensiklopedia Sastra Indonesia - Badan Pengembangan dan Pembinaan Bahasa, Kementerian Pendidikan dan Kebudayaan Republik Indonesia http://lakonhidup.com/2019/04/28/wakyat https://www.google.com/amp/s/news.okezo ne.com/amp/2019/02/14/337/2018172/pe ran-dan-fungsi-kaum-perempuan-di-politikharus-diperkuat 